\title{
Nutritional Value, Mineral Composition, Secondary Metabolites, and Antioxidant Activity of Some Wild Geophyte Sedges and Grasses
}

\author{
Saud L. Al-Rowaily ${ }^{1}$, Ahmed M. Abd-ElGawad ${ }^{1,2}, * \mathbb{1}$, Suliman M. Alghanem ${ }^{3}$, \\ Wafa'a A. Al-Taisan ${ }^{4}$ and Yasser A. El-Amier ${ }^{2}$ D \\ 1 Plant Production Department, College of Food \& Agriculture Sciences, King Saud University, P.O. Box 2460, \\ Riyadh 11451, Saudi Arabia; srowaily@ksu.edu.sa \\ 2 Department of Botany, Faculty of Science, Mansoura University, Mansoura 35516, Egypt; \\ yasran@mans.edu.eg \\ 3 Biology Department, Faculty of Science, Tabuk University, Tabuk 71491, Saudi Arabia; s-alghanem@ut.edu.sa \\ 4 Department of Biology, College of Science, Imam Abdulrahman Bin Faisal University, P.O. Box 1982, \\ Dammam 31441, Saudi Arabia; waltaisan@iau.edu.sa \\ * Correspondence: aibrahim2@ksu.edu.sa or dgawad84@mans.edu.eg; Tel.: +20-1003438980 or \\ $+966-562680864$
}

Received: 11 November 2019; Accepted: 2 December 2019; Published: 4 December 2019

\begin{abstract}
Geophytes are plants with underground storage organs including bulbs, corms, tubers, and rhizomes, often physiologically active and able to survive during harsh environmental conditions. This study is conducted to assess the nutritive value, mineral composition, bioactive metabolites, and antioxidant activity of five wild geophytes (Cyperus capitatus, C. conglomeratus, Elymus farctus, Lasiurus scindicus, and Panicum turgidum) collected from the Nile Delta coast and inland desert. The proximate composition including dry matter, moisture content, ash content, fiber, fat, protein, sucrose, and glucose were determined. Also, total carbohydrates, total digestible nutrients (TDN), and nutritive values were calculated. Macro- and micro-minerals were also determined in the studied geophytes. Total phenolics, total flavonoids, alkaloids, saponins, and tannins were determined. Antioxidant activity was evaluated based on 2,2-diphenyl-1-picrylhydrazyl (DPPH) radicle scavenging. Based on the nutritive value, the studied geophytes are ranked as follows: E. farctus $>$ C. conglomeratus $>$ L. scindicus $>$ P. turgidum $>$ C. capitatus. The mineral analysis reveals a sufficient amount of macroand micro-elements in the studied geophytes while the microelements levels in the studied wild plants exist as $\mathrm{Fe}>\mathrm{Mn}>\mathrm{Zn}>\mathrm{Cu}$. Cyperus conglomeratus attained the highest concentrations of all determined secondary metabolites. On the other hand, C. conglomeratus, C. capitatus, and P. turgidum extracts showed strong scavenging activity $\left(\mathrm{EC}_{50}<1 \mathrm{mg} \mathrm{mL}^{-1}\right)$, while extracts of $E$. farctus and $L$. scindicus exhibited moderate scavenging activity $\left(1 \leq \mathrm{EC}_{50} \leq 2 \mathrm{mg} \mathrm{mL}^{-1}\right)$. The present data reveal that geophytes under investigation could be used as good forage plants, especially in arid habitats. In addition, $C$. conglomeratus could be a potentially important candidate for natural antioxidants as it attained high contents of the bioactive constituents.
\end{abstract}

Keywords: Cyperus; grasses; nutritive value; forage; minerals; drought; medicinal plants

\section{Introduction}

In developing countries, the high population growth rates combined with limited and rapidly decreasing land for food and forage production have led to the need to intensify agricultural production to bridge the gap between food needs and supplies as well as to ensure appropriate human nutrition. Intensification, in the ruminant production systems, implies extending the feed sustainable resource 
base to compensate for the deficiencies of rangeland and natural grasslands, moreover increasing the low quality and seasonal nature of feed resources [1].

Geophytes are plants with underground storage organs that include bulbs, corms, tubers, and rhizomes, which appear to be promising raw materials for various economic uses [2]. Geophytes are often physiologically active even when they lack leaves; they can survive during harsh environmental conditions as they reserve carbohydrates and water until the favorable conditions come again. There are no evergreen plants that are geophytes in natural habitats, whereas geophytes are those vascular plants that survive unfavorable conditions for growth [3]. These geophytes have high diversity in the Mediterranean-type ecosystems, where they are considered as most common in seasonal climates [4].

Forages are plants or parts of plants eaten by domesticated animals and wildlife. Herbs (Poaceae family) are normally herbaceous, which indicate that they produce a seed, do not create woody tissues, and die at the end of a growing season [5]. The economic importance of grasses lies in their role as an important food source, which produces edible grain, the bulk of which, provides a rich source of carbohydrates, protein, oil, and some vitamins [6]. In addition, grasses have adapted to the full range of environmental extremes from the coldest regions and highest elevations, and from fully aquatic habitats to deserts. On the other hand, plants of the genus Cyperus or sedges (Cyperaceae family) include some common wild species found in the desert habitat. Some types of this family are used in traditional folk medicine and as food, as well as the vegetative yield used as forage for domestic and wild animals [7].

Therefore, communities in arid regions have a long history of using sustainable renewable resources for uncultivated areas to produce more food for people, animal feed, and the manufacture of our local raw materials [8,9]. Mashaly et al. [10] studied the nutritive value of some members of Cyperaceae (Bolboschoenus glaucus, Cyperus laevigatus, Schoenoplectus litoralis) and Poaceae (Echinochloa stagnina, Leptochloa fusca, Panicum repens, Paspalidium geminatum, Schoenoplectus litoralis, and Sorghum virgatum). Heneidy and Halmy [11] reported that Panicum turgidum has high nutritive value and is considered a good forage plant.

This study is conducted to assess the nutritional value, mineral composition, secondary metabolites, and antioxidant activity of five wild-grown geophytes; two of Cyperaceae (Cyperus capitatus and C. conglomeratus) and three of Poaceae (Elymus farctus, Lasiurus scindicus, and Panicum turgidum) collected from the Egyptian coastal desert (Deltaic Mediterranean coast) and inland desert (Wadi Hagoul).

\section{Results and Discussion}

\subsection{Proximate Composition}

Dry matter, moisture, ash, and fiber contents of the five geophytes showed non-significant differences between the studied geophytes (Table 1). The value difference was not significant among the studied plant species. Dry matter content is the actual amount of nutrients that leave water, acids, and bases, if any. In the present study, the highest (91.67\%) dry matter content was determined in $C$. conglomeratus, and the lowest $(87.10 \%)$ value was obtained from C. capitatus. Data obtained from this study are in harmony with other reported wild species such as Cyperus laevigatus, Bolboschoenus glaucus, Panicum repens, and Sorghum virgatum [10]. The dry matter content of the plants varies according to various factors such as plant species, parts of the plant, growing conditions, soil and environment [12]. In our view, the high content of dry matter in the studied plants can be ascribed to the fact that these plants grow naturally in sandy habitats with low content of water.

The moisture content of plants, ranging from $8.33 \%$ in C. conglomeratus to $12.90 \%$ in C. capitatus, makes them more stable during storage and packaging. The ash content oscillated between $8.62 \%$ for P. turgidum and $10.75 \%$ for C. capitatus. On the other hand, there was a slight variation between the crude fibers of the studied plant (Table 1). The highest (13.84\%) and lowest $(11.97 \%)$ crude fiber were from $P$. turgidum and C. conglomeratus, respectively. The range of the crude fibers in the studied plants are in harmony with that reported for C. rotundus [13], C. laevigatus, and P. geminatum [10], while it was 
lower than those reported in B. glaucus, S. litoralis, E. stagnina, L. fusca, P. repens, and S. virgatum [10]. These variations may probably reflect the difference in origin, season of use (wet season versus dry season), plant species, and growth phase [14].

Table 1. Proximate composition (on dry matter basis) of the studied geophytes collected from the Egyptian desert.

\begin{tabular}{|c|c|c|c|c|c|c|}
\hline $\begin{array}{l}\text { Proximate } \\
\text { Composition }\end{array}$ & $\begin{array}{l}\text { Cyperus } \\
\text { capitatus }\end{array}$ & $\begin{array}{c}\text { Cyperus } \\
\text { conglomeratus }\end{array}$ & $\begin{array}{l}\text { Elymus } \\
\text { farctus }\end{array}$ & $\begin{array}{l}\text { Lasiurus } \\
\text { scindicus }\end{array}$ & $\begin{array}{l}\text { Panicum } \\
\text { turgidum }\end{array}$ & $p$-Value \\
\hline Dry matter \% & $87.10 \pm 4.94^{a}$ & $91.67 \pm 3.65^{a}$ & $89.80 \pm 5.09^{a}$ & $90.46 \pm 3.12^{a}$ & $90.13 \pm 5.11^{a}$ & 0.58 \\
\hline Moisture \% & $12.90 \pm 1.29^{a}$ & $8.33 \pm 0.83^{a}$ & $10.20 \pm 1.02^{\mathrm{a}}$ & $9.54 \pm 0.95^{\mathrm{a}}$ & $9.87 \pm 0.99^{a}$ & 0.51 \\
\hline Ash \% & $10.75 \pm 1.07^{\mathrm{a}}$ & $10.54 \pm 1.05^{\mathrm{a}}$ & $9.39 \pm 0.94^{\mathrm{a}}$ & $9.07 \pm 0.91^{\mathrm{a}}$ & $8.62 \pm 0.86^{\mathrm{a}}$ & 0.47 \\
\hline Fiber \% & $12.51 \pm 1.25^{\mathrm{a}}$ & $11.97 \pm 0.98^{\mathrm{a}}$ & $13.40 \pm 1.34^{\mathrm{a}}$ & $12.89 \pm 1.29^{a}$ & $13.84 \pm 0.88^{a}$ & 0.23 \\
\hline Fat $\%$ & $3.89 \pm 0.28^{\mathrm{cd}}$ & $3.19 \pm 0.23^{d}$ & $5.13 \pm 0.38^{a b}$ & $4.61 \pm 0.34 \mathrm{bc}$ & $5.87 \pm 0.43^{\mathrm{a}}$ & 0.0013 \\
\hline Protein \% & $16.38 \pm 1.20 \mathrm{ab}$ & $17.13 \pm 1.25^{a}$ & $13.50 \pm 0.99 \mathrm{~cd}$ & $14.88 \pm 1.09 \mathrm{bc}$ & $12.06 \pm 0.88^{\mathrm{d}}$ & 0.0004 \\
\hline Sucrose $\%$ & $1.89 \pm 0.14^{\mathrm{a}}$ & $1.98 \pm 0.15^{\mathrm{a}}$ & $1.74 \pm 0.13^{\mathrm{a}}$ & $1.81 \pm 0.13^{\mathrm{a}}$ & $1.52 \pm 0.11^{\mathrm{a}}$ & 0.98 \\
\hline Glucose $\%$ & $0.72 \pm 0.05^{\mathrm{a}}$ & $0.94 \pm 0.07^{\mathrm{a}}$ & $0.78 \pm 0.06^{\mathrm{a}}$ & $0.82 \pm 0.06^{\mathrm{a}}$ & $0.68 \pm 0.05^{\mathrm{a}}$ & 0.78 \\
\hline
\end{tabular}

Values are mean of triplicates \pm standard error. Different letters within each measurement mean values of significant variation at $p \leq 0.05$.

The total protein content of feed plants is considered as an indicator of the nutritional value for ruminants. In the present study, the protein content of the studied geophytes was relatively high in general $(>10.0 \%)$ compared with other grasses (3.0-10.0\%) reported by El-Amier and Abdullah [15], Abdou Bouba et al. [14], and Imam et al. [16]. The crude protein contents showed a significant variation ( $p=0.0013$ ) among the investigated plants, and it was varied between $12.06 \%$ (P. turgidum) to $17.13 \%$ (C. conglomeratus). The wild edible plants such as Malva neglecta and Polygonum bistorda had $2.35 \%$ and $11.56 \%$ protein contents, respectively $[17,18]$. In the cultivated forage such as Medicago sativa, Trifolium alexandrinum, E. stagnina, and Cynodon dactylon, protein contents were 19.70\%, 17.19\%, 16.38\%, and $12.63 \%$, respectively $[19,20]$. The content of protein in the present study was comparable to those reported for E. stagnina and L. fusca, while it was higher than those reported in C. rotundus, C. laevigatus, P. geminatum, B. glaucus, S. litoralis, P. repens, S. virgatum [10], and P. turgidum [11].

Although fats are a concentrated source of energy, they do not constitute a major source of energy from forages [21]. The fat contents of the studied plant revealed a highly significant variation $(p=$ $0.0004)$. The highest value of lipids (5.87\%) was recorded in P. turgidum, and the lowest value $(3.19 \%)$ was that of $C$. conglomeratus (Table 1). This is in agreement with the results of other reports [22,23], but it is higher than those reported by Zahran and El-Amier [1]. However, lower contents of lipids were reported in the other members of Cyperaceae and Poaceae [10] compared to the present results.

Regarding the contents of glucose and sucrose, comparable amounts were determined among the studied geophytes (Table 1$)$. The highest concentrations of glucose $(0.94 \%)$ and sucrose $(1.98 \%)$ were determined in C. conglomeratus. It was reported that the contents of glucose and sucrose in C. laevigatus were $0.34 \%$ and $4.74 \%$, respectively [10].

In any forage plants, the nutritional status depends upon the contents of protein, lipids, and carbohydrates. However, the palatability and digestibility of each plant depend on the composition of these organic nutrients, as well as minerals, vitamins, and antinutritional compounds [24]. Some calculated parameters, including total carbohydrates, energy, and total digestible nutrients (TDNs), were determined for the five studied geophytes. Slight variations in both carbohydrates and TDNs were observed among the studied plants (Figure 1). Carbohydrate value ranged from $56.48 \%$ in C. capitatus to $59.61 \%$ in P. turgidum. The dry matter of forage crops should contain about $50-80 \%$ carbohydrates, while if this ratio is too low, then supplements can be added [24]. The average carbohydrate contents of Cyperaceae and Poaceae were comparable.

Elymus farctus showed the highest energy level at $324.61 \mathrm{kcal} 100 \mathrm{~g}^{-1} \mathrm{DW}$, while C. capitatus

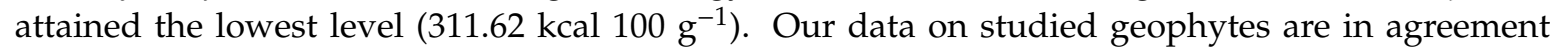
with that reported for other species of Cyperaceae (C. laevigatus, B. glaucus, S. litoralis,) and Poaceae (P. geminatum, P. repens, E. stagnina, and L. fusca), while it was lower than the metabolizable energy of $S$. 
virgatum (294.56 kcal $\left.100 \mathrm{~g}^{-1} \mathrm{DW}\right)$. On the other hand, the TDNs are used to describe energy available in food to animals after digestion losses have been deduced. The literature data on the annual mean of the TDN value showed a figure of $75 \%$ [25]. In the studied species, the average value of a Cyperaceae member was $57.54 \%$, while the average of a Poaceae species was $60.31 \%$ (Figure 1 ). These results are comparable to those obtained by Gill et al. [26] on twelve barley varieties (overall mean of $64.8 \%$ ) and Mashaly et al. [10] on some members of Cyperaceae (57.12-60.74\%) and Poaceae (51.92-62.82\%).

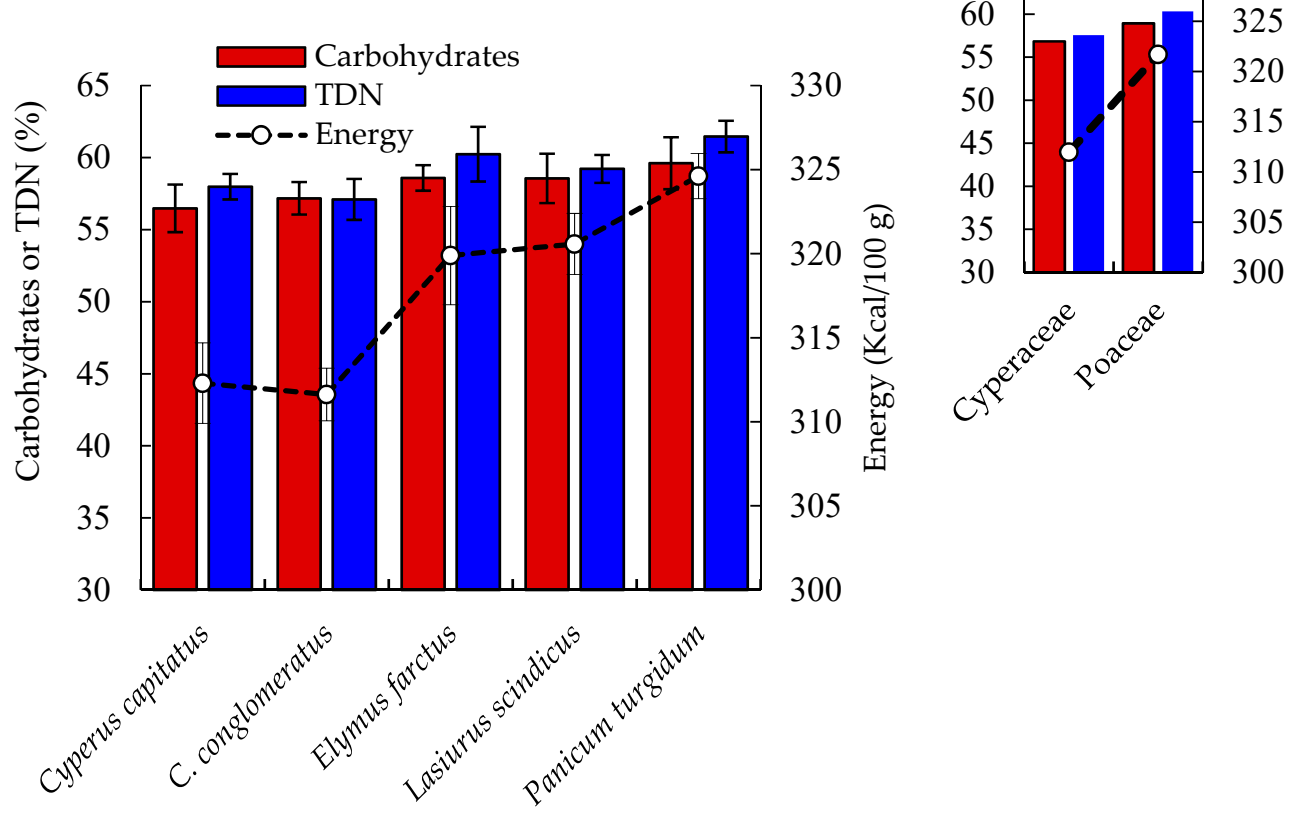

Figure 1. Carbohydrates, total digestible nutrients (TDN), and energy of the selected geophyte plants in the Egyptian desert. Values are mean $(n=3)$ with standard error bars.

\subsection{Mineral Content}

Mineral composition has essential structural and physiological roles in animals as well as maintaining livestock health. In this study, the concentrations of the macro- $(\mathrm{K}, \mathrm{Ca}, \mathrm{Mg}$, and $\mathrm{Na})$ and micro-elements ( $\mathrm{Fe}, \mathrm{Mn}, \mathrm{Zn}$, and $\mathrm{Cu}$ ) were estimated in the five studied geophytes (Figures 2 and 3). According to the concentration in the studied geophytes, the macro-minerals can be sequenced as follows: $\mathrm{Ca}>\mathrm{K}>\mathrm{Mg}>\mathrm{Na}$, while the micro-minerals can be ordered as $\mathrm{Fe}>\mathrm{Mn}>\mathrm{Zn}>\mathrm{Cu}$. Moreover, different plant species had variable mineral concentrations.

The mineral content of studied plant species ranged from $29.8-40.9 \mathrm{mg} \mathrm{g}^{-1} \mathrm{DW}$ (Ca), 19.7-28.5 $\mathrm{mg} \mathrm{g}^{-1} \mathrm{DW}(\mathrm{K}), 11.3-17.2 \mathrm{mg} \mathrm{g}^{-1} \mathrm{DW}(\mathrm{Mg}), 5.78-8.16 \mathrm{mg} \mathrm{g}^{-1} \mathrm{DW}(\mathrm{Na}), 16.93-38.44 \mu \mathrm{g} \mathrm{g}^{-1}(\mathrm{Fe})$, 14.20-21.14 $\mu \mathrm{g} \mathrm{g}^{-1}(\mathrm{Zn}), 16.93-27.16 \mu \mathrm{g} \mathrm{g}^{-1}(\mathrm{Mn})$, and 2.76-4.75 $\mu \mathrm{g} \mathrm{g}^{-1}(\mathrm{Cu})$ (Figures 2 and 3). Our results were similar to those reported by Abbasi et al. [27] on white clover and Vejnovic et al. [28] on natural grasslands. According to the Agricultural Research Council (ARC) [29] and the National Research Council (NRC) [30] systems, the requirement for mineral nutrients for gestating beef cows or lactating beef cows is $38.0 \mathrm{mg} \mathrm{kg}^{-1}$ for $\mathrm{K}, 15.4 \mathrm{mg} \mathrm{kg}^{-1}$ for $\mathrm{Ca}, 3.0 \mathrm{mg} \mathrm{kg}^{-1}$ for $\mathrm{Mg}, 6.8 \mathrm{mg} \mathrm{kg}^{-1}$ for $\mathrm{Na}, 45.0 \mu \mathrm{g} \mathrm{kg}^{-1}$ for $\mathrm{Zn}, 2.0 \mu \mathrm{g} \mathrm{kg}^{-1}$ for $\mathrm{Mn}$, and $7.1 \mu \mathrm{g} \mathrm{kg}{ }^{-1}$ for $\mathrm{Cu}$. Thus the studied plant species of Poaceae and Cyperaceae have suitable contents of the minerals. In general, Cyperaceae members attained higher contents of $\mathrm{Na}$, Fe, and Mn compared to Poaceae members, while the latter have higher contents of K (Figures 2 and 3). 


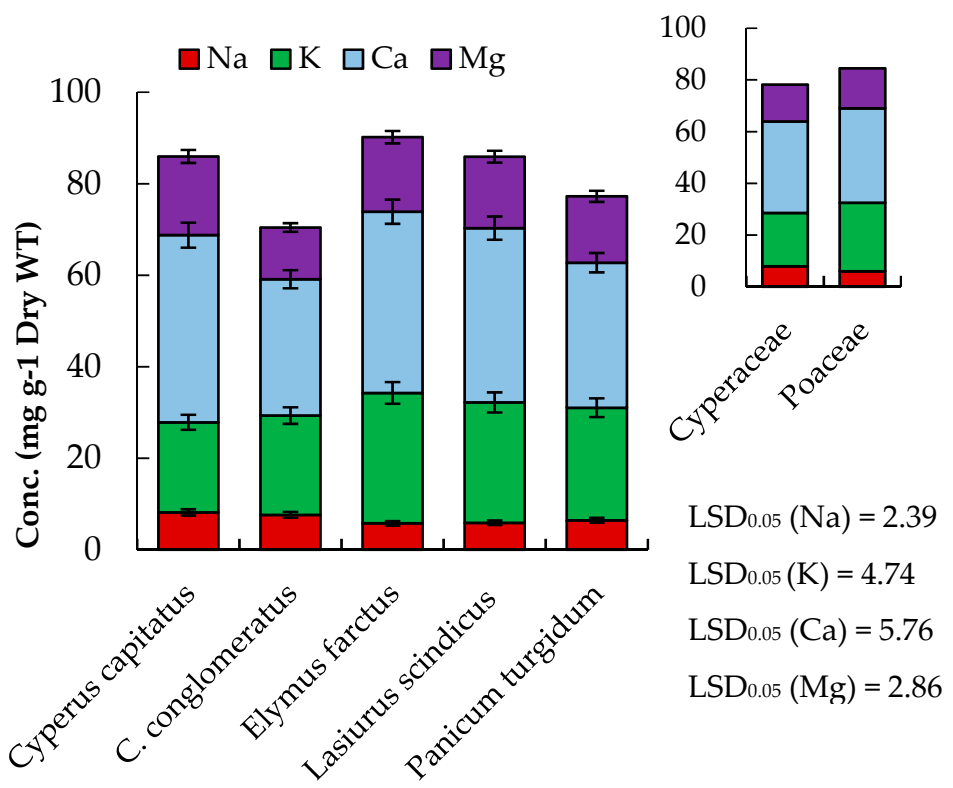

Figure 2. Macro-mineral composition of selected geophytes under study. Values are means $(n=3)$ with standard error bars. $\mathrm{LSD}_{0.05}$ is the least significant difference at the probability level of 0.05 .

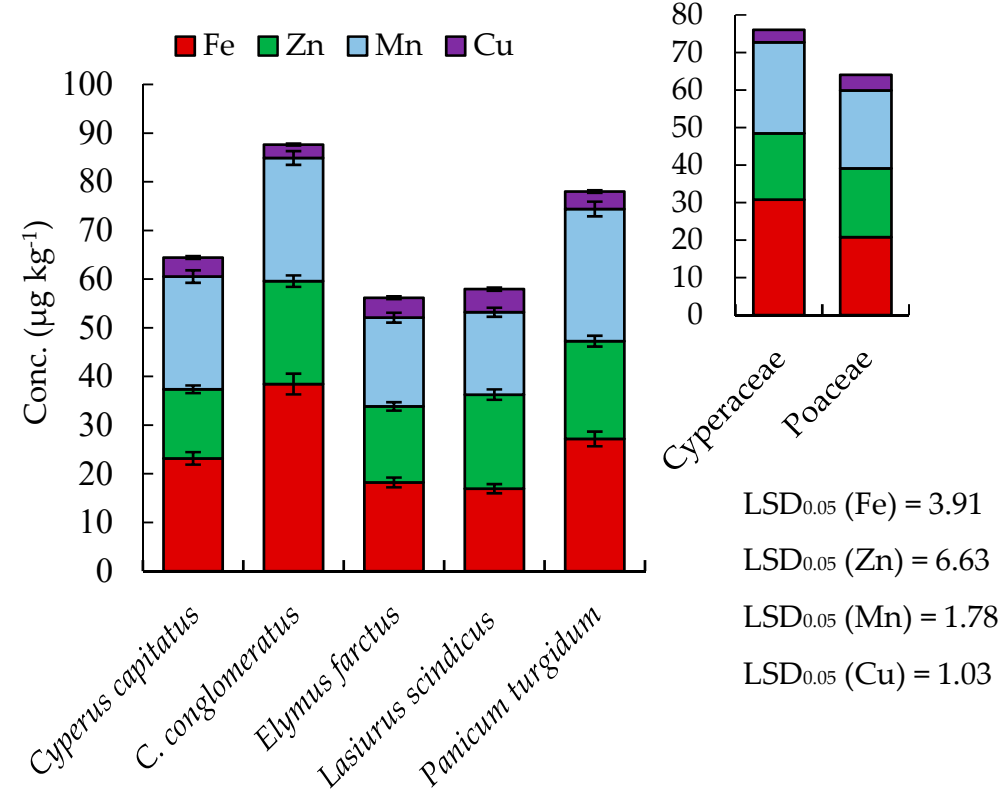

Figure 3. Micro-mineral composition of selected geophytes. Values are an average $(n=3)$ with standard error bars. $\mathrm{LSD}_{0.05}$ is the least significant difference at the probability level of 0.05 .

\subsection{Secondary Metabolites}

The dry and saline habitats of the studied geophytes species are hypothesized as triggers for the synthesis of various secondary metabolites such as phenolics, flavonoids, alkaloids, saponins, and many other compounds that have protective and medicinal properties [31]. The present results showed that the contents of total phenolics, alkaloids, total flavonoids, saponins, and tannins were in the range of 26.34-9.59, 21.84-6.08, 18.27-5.31, 41.16-10.13, and 26.10-4.13 $\mathrm{mg} \mathrm{g}^{-1} \mathrm{DW}$, respectively (Table 2). Cyperus conglomeratus attained the highest contents of all investigated secondary metabolites, where it attained about double-fold than $C$. capitatus regarding all secondary metabolites and more than double fold for the tested grasses (E. farctus, L. scindicus, and P. turgidum). These results are consistent 
with to those reported by Canty et al. [32] on Lolium perenne, and Kara and Sürmen [33] on rangeland and pasture plants of the genus of Lotus, Astragalus, and Onobrychis. It is worth mentioning here that $C$. conglomeratus has been reported to have several bioactive compounds such as flavonoids [25], glycosides, sterols, tannins, and terpenoids [34]. Cyperus capitatus has been reported to contained several bioactive constituents such as essential oil [35], quinones, and flavonoids [36].

Table 2. Secondary compounds $\left(\mathrm{mg} \mathrm{g}^{-1} \mathrm{DW}\right)$ of the studied geophytes collected from the Egyptian desert.

\begin{tabular}{lccccc}
\hline $\begin{array}{c}\text { Secondary } \\
\text { Compounds }\end{array}$ & $\begin{array}{c}\text { Cyperus } \\
\text { capitatus }\end{array}$ & $\begin{array}{c}\text { Cyperus } \\
\text { conglomeratus }\end{array}$ & Elymus farctus & $\begin{array}{c}\text { Lasiurus } \\
\text { scindicus }\end{array}$ & $\begin{array}{c}\text { Panicum } \\
\text { turgidum }\end{array}$ \\
\hline Total phenolics & $16.02 \pm 0.86^{\mathrm{b}}$ & $26.34 \pm 1.41^{\mathrm{a}}$ & $13.57 \pm 0.73^{\mathrm{bc}}$ & $9.59 \pm 0.51^{\mathrm{d}}$ & $10.69 \pm 0.57^{\mathrm{cd}}$ \\
Alkaloids & $15.15 \pm 0.81^{\mathrm{b}}$ & $21.84 \pm 1.17^{\mathrm{a}}$ & $16.10 \pm 0.86^{\mathrm{b}}$ & $6.89 \pm 0.37^{\mathrm{c}}$ & $6.08^{\mathrm{a}} \pm 0.33^{\mathrm{c}}$ \\
Total flavonoid & $10.57 \pm 0.57^{\mathrm{b}}$ & $18.27 \pm 0.98^{\mathrm{a}}$ & $8.02 \pm 0.43^{\mathrm{c}}$ & $5.31 \pm 0.28^{\mathrm{d}}$ & $5.82^{\mathrm{a}} \pm 0.31^{\mathrm{d}}$ \\
Saponins & $19.59 \pm 1.05^{\mathrm{b}}$ & $41.16 \pm 2.21^{\mathrm{a}}$ & $18.60 \pm 1.00^{\mathrm{c}}$ & $10.13 \pm 0.54^{\mathrm{d}}$ & $11.41^{\mathrm{a}} \pm .61^{\mathrm{d}}$ \\
Tannins & $12.42 \pm 0.67^{\mathrm{b}}$ & $26.10 \pm 1.40^{\mathrm{a}}$ & $12.80 \pm 0.69^{\mathrm{b}}$ & $5.46 \pm 0.29^{\mathrm{c}}$ & $4.13^{\mathrm{b}} \pm 0.22^{\mathrm{c}}$ \\
\hline
\end{tabular}

Values are mean of triplicates \pm standard error. Different letters within each measurement mean values of significant variation at $p \leq 0.05$.

Antinutrients or antinutritional factors are the compounds that act to reduce nutrient intake, digestion, absorption, and utilization, and also produce adverse effects. The major antinutrients are alkaloids, flavonoids, saponins, tannins, oxalates, cyanogenic glycosides, phytic acid, gossypol, goitrogens, lectins, chlorogenic acid, protease and amylase inhibitors. The content of antinutritional factors in the plant depends on secondary metabolites, which vary with plant species, phenological periods, and environmental conditions [37]. Excess content of saponins in the fodder adversely affects animals, causing a depression of growth rates, inhibiting enzyme activity, and leading to a reduction in nutrient absorption in the digestive tract, as well as that saponins are bitter-tasting molecules [38]. In addition, tannins are other compounds with high molecular weight and are soluble in water, when herbivorous grazed plants with a high content of tannins, they form a less digestive complex with dietary proteins and reduce the chances of growth and survival of animals [33]. Tannins are also characterized by an astringent taste, therefore, it is considered as antinutritional compounds [38]. Alkaloids are also commonly found in about $20 \%$ of vascular plant species, and when grazed by animals, they affect the nervous system and can cause paralysis and sudden deaths [39]. Overall, C. conglomeratus attained a high content of the secondary metabolites, which could be considered as an antinutritional compound. Therefore, this plant may be not suitable as an animal fodder although it has a high nutritive value. Some members of Cyperaceae are known to possess antifeedants compounds such as coumaran, remirol, cyperaquinone, furoquinones, and scabequinone [40].

\subsection{Antioxidant Activity}

The extracts of the five studied geophytes showed a significant increase in the scavenging activity of 2,2-diphenyl-1-picrylhydrazyl (DPPH) in a dose-dependent manner (Figure 4). At $1 \mathrm{mg} \mathrm{mL}^{-1}$, the extracts of C. conglomeratus, E. farctus, P. turgidum, C. capitatus, and L. scindicus showed scavenging activities of $63.87 \%, 54.26 \%, 52.31 \%, 51.52 \%$, and $50.79 \%$, respectively. Based on the $\mathrm{EC}_{50}$ values, the studied geophytes can be ordered as follows: C. conglomeratus $>$ C. capitatus $>$ P. turgidum $>$ L. scindicus $>$ E. farctus, where they attained the values of $0.65,0.87,0.93,1.27$, and $1.30 \mathrm{mg} \mathrm{mL}^{-1}$, respectively (Figure 4). However, the positive control or standard (catechol) attained an $\mathrm{EC}_{50}$ value of $0.17 \mathrm{mg} \mathrm{mL}^{-1}$. These data reflect that members of Cyperaceae are considered better candidates as antioxidant natural resources than the Poaceae members.

The antioxidant capacity of $C$. conglomeratus and $C$. capitatus can be attributed to the high content of bioactive compounds [9,41]. Moreover, C. conglomeratus is characterized by various biological activities such as anthelmintic, antidiarrheal, antidiabetic [41,42], antioxidant, antimicrobial [34,43], and cytotoxic activity [9]. 


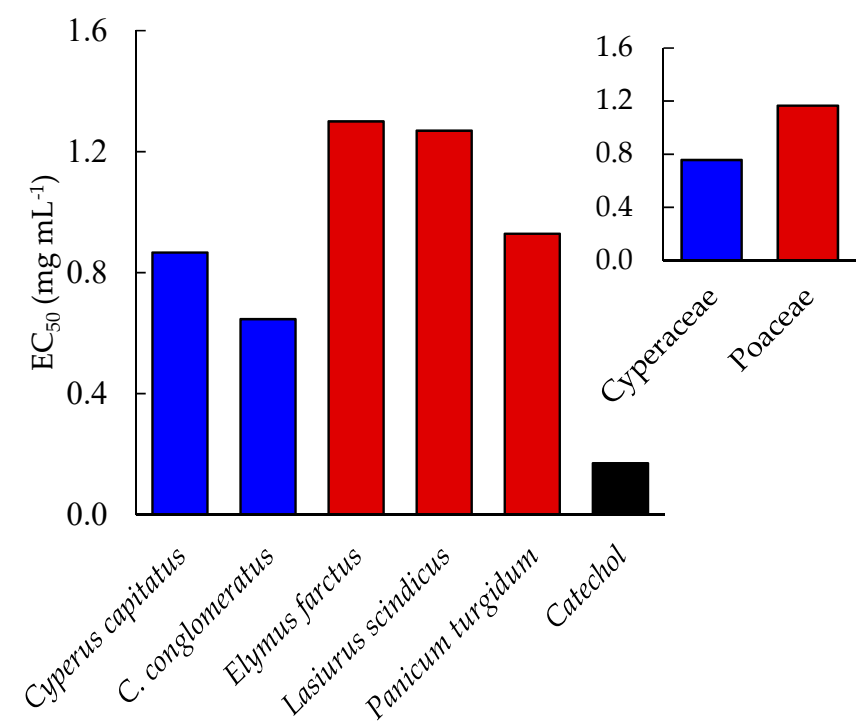

Figure 4. $\mathrm{EC}_{50}$ values of the different studied geophytes and catechol (standard).

On the other hand, P. turgidum has been reported to possess anti-inflammatory, antibacterial, antihepatotoxic, antifungal, and cytotoxic activities [44-48]. These biological activities were mainly due to steroidal saponins, which are characterized components of this genus [46]. In addition, this plant has other bioactive compounds such as phenolic acids (caffeic, ferulic, $p$-coumaric, protocatechuic, and $p$-hydroxybenzoic), and flavonoids (rutin and quercetin glycosides) [45].

\section{Materials and Methods}

\subsection{Collection and Preparation of Plant Materials}

Five wild geophyte species were collected during the period of March 2018 from naturally growing populations distributed in different habitats of the northern part of the Mediterranean Sea (Nile Delta coast) and Eastern Desert regions (Wadi Hagoul) of Egypt (Figure 5). Two geophytes belong to Cyperaceae (C. capitatus and C. conglomeratus) and three belong to Poaceae (E. farctus, L. scindicus, and P. turgidum) (Table 3 and Figure 6). The plants were identified by Dr. Yasser El-Amier (author), and voucher specimens were deposited in the herbarium of the Faculty of Science at Mansoura University, Egypt.

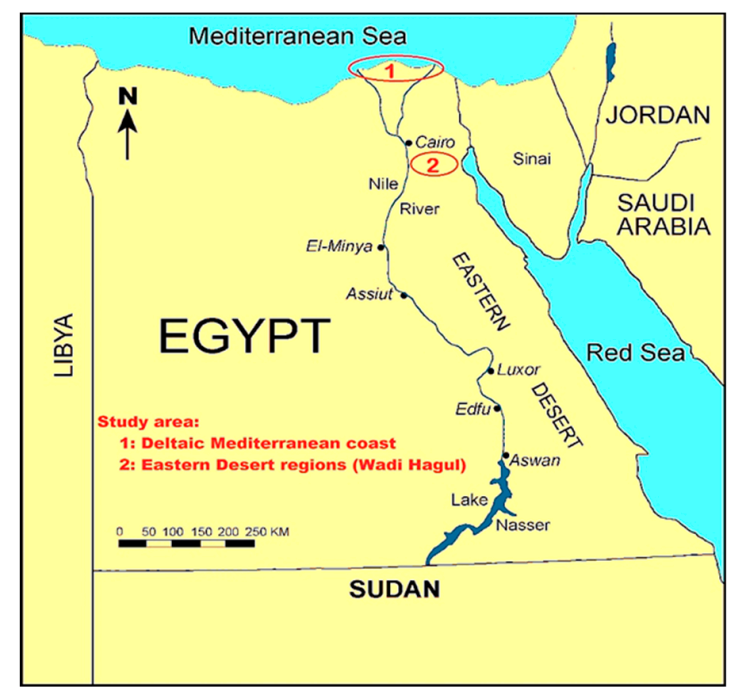

Figure 5. Map of Egypt showing the locations of plant sampling. 
Table 3. Plant species name, family, duration, and chorotype of studied wild geophytes naturally growing in the Egyptian desert.

\begin{tabular}{cccccc}
\hline Botanical Name & Family & Common Name & Duration & Chorotype & Voucher Code \\
\hline Cyperus capitatus Vand. & Cyperaceae & Seed & Perennial & ME & Mans.030303012 \\
$\begin{array}{c}\text { Cyperus conglomeratus Rottb. } \\
\text { Elymus farctus (Viv.) Runem. }\end{array}$ & Cyperaceae & Seed, Oshb & Perennial & SA-SI + S-Z & Mans.030303008 \\
ex Melderis & Poaceae & Gazzoof & Perennial & ME & Mans.160506018 \\
Lasiurus scindicus Henrard. & Poaceae & Sammat & Perennial & SA-SI + S-Z & Mans.161219003 \\
Panicum turgidum Forssk. & Poaceae & Thommam, & Perennial & SA-SI & Mans.161620007 \\
\hline
\end{tabular}

ME: Mediterranean; SA-SI: Saharo-Sindian; S-Z: Sudano-Zambezian.

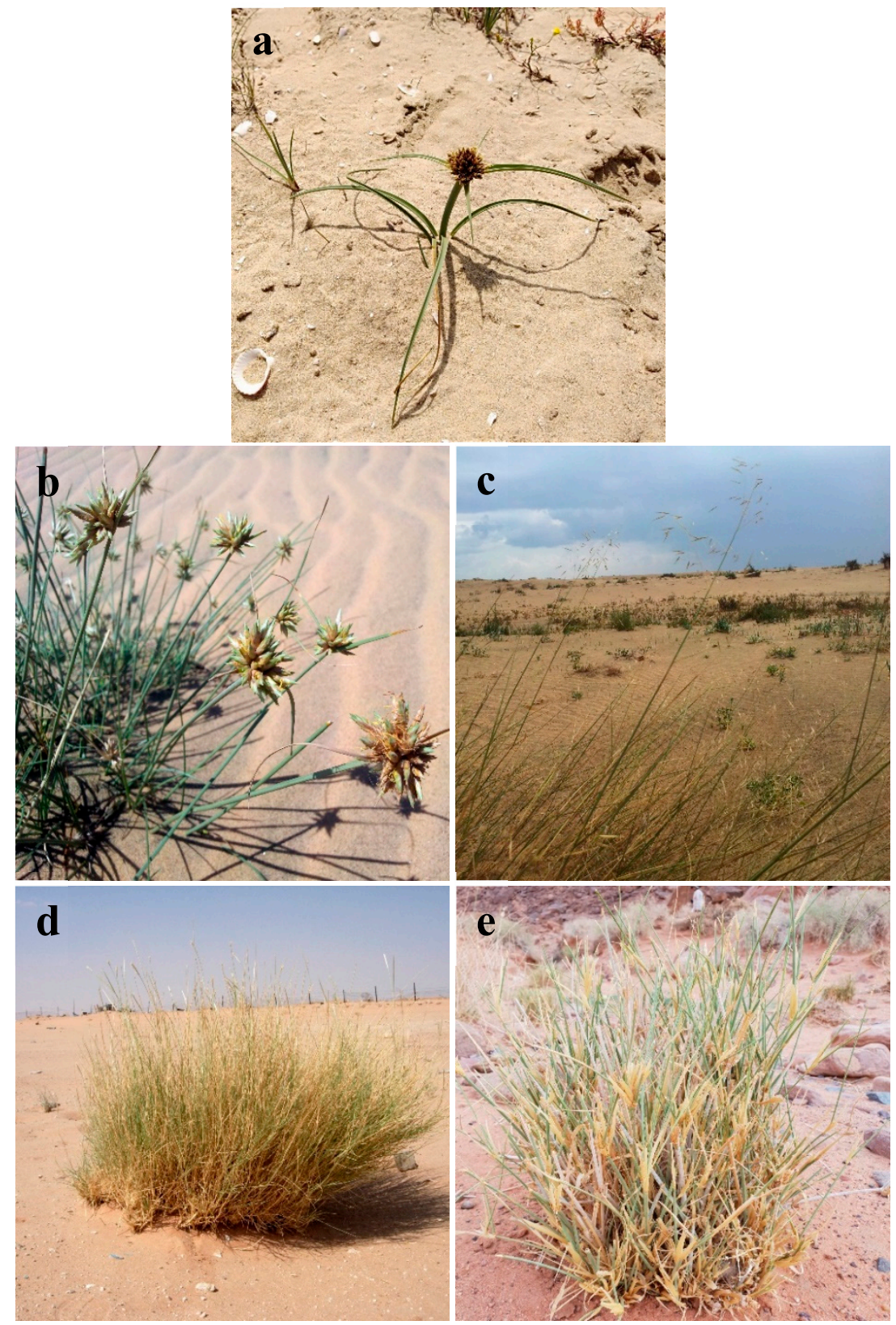

Figure 6. Close view of the five studied geophytes. (a) Cyperus capitatus, (b) Cyperus conglomeratus, (c) Elymus farctus, (d) Lasiurus scindicus, and (e) Panicum turgidum. 
The collected aerial parts were handily cleaned and the died or yellow leaves were removed. The samples were washed three times by distilled water to remove dust and other residues, dried at room temperature $\left(25 \pm 2{ }^{\circ} \mathrm{C}\right)$ in a shaded place for several days till complete dryness and ground into powder. Finally, the dried samples were stored in paper bags until further analyses.

\subsection{Proximate Composition}

Dry matter, moisture content, total ash content, fat, and fiber were determined in the collected aerial parts of the plants following the methods of AOAC [49]. Total nitrogen was determined by the micro-Kjeldahl method [50]. Protein contents of the plant species were determined by multiplying $\mathrm{N}$ contents by the factor 6.25 [49]. Glucose was determined according to the method of Feteris [51], while sucrose content was estimated following the method of Handel [52].

The total carbohydrate content for each sample was calculated by "difference", in which the summation of the percentages of all the other proximate components was subtracted from 100 [49]. The potential energy ( $\mathrm{kcal} 100 \mathrm{~g}^{-1} \mathrm{DW}$ ) was carried out using the Atwater general factors as described by FAO [53] by multiplying the values obtained for protein, carbohydrates, and fat by 4, 3.75, and 9, respectively; the results are expressed in kcal. The TDN was estimated according to the equation described by Abu-El-Naga and EL-Shazly [54] as follows:

$$
\operatorname{TDN}(\%)=0.623(100+1.25 \mathrm{EE})-\mathrm{P} 0.72
$$

where EE is the percentage of ether extract, and $\mathrm{P}$ is the percentage of crude protein.

\subsection{Minerals Content Analysis}

About $0.1 \mathrm{~g}$ of each air-dried powder of the plant aerial parts were digested by using concentrated $\mathrm{HNO}_{3}$ and gently heated until all the organic matter disappeared and the solution turned quite clear [55]. The clear samples were made up to a known volume using distilled water. $\mathrm{Na}$ and $\mathrm{K}$ were determined in all samples by a flame photometer (Jenway PFP7, Felsted, UK), while calcium, magnesium, copper, zinc, iron, and manganese were estimated using an atomic absorption spectrometer (A Perkin-Elmer, Model 2380, Waltham, MA, USA).

\subsection{Phytochemical Analysis}

The total phenolics content was determined according to the method of Sadasivam and Manickam [56]. In brief, a known weight $(0.1 \mathrm{~g})$ of dried plant tissue was ground in $80 \%(v / v)$ aqueous methanol. The mixture was filtrated via muslin and centrifugated at 10,000 rpm for $20 \mathrm{~min}$. The supernatant was then evaporated, and the residue was redissolved in distilled water $(5 \mathrm{~mL})$. A mixture of $0.5 \mathrm{~mL}$ extract, $2.5 \mathrm{~mL}$ distilled water, $2 \mathrm{~mL} \mathrm{NaCO}_{3}(20 \%)$, and $0.5 \mathrm{~mL}$ of Folin-Ciocalteu reagent was prepared and incubated for $40 \mathrm{~min}$ in a dark condition. Using a spectrophotometer (Spectronic 21D model, Milton Roy, CA, USA), the absorbance was measured at $725 \mathrm{~nm}$. The content of total phenolics was determined based on a standard curve of gallic acid and expressed as mg gallic acid equivalent $\mathrm{g}^{-1} \mathrm{DW}$.

Tannins content was determined spectrophotometrically according to Sadasivam and Manickam [56]. One gram of plant tissue was extracted by $50 \mathrm{~mL}$ of methanol $(80 \%, v / v)$ with continuous shaking for $24 \mathrm{~h}$. The homogenate was centrifuged, and the supernatant was collected and raised to a known volume. About $5 \mathrm{~mL}$ of vanillin hydrochloride reagent $(8 \% \mathrm{HCl}$ in methanol and $4 \%$ vanillin in methanol 1:1 $\mathrm{v} / \mathrm{v}$ ) was added to $1 \mathrm{~mL}$ of the supernatant and incubated at room temperature for $20 \mathrm{~min}$. The optical density was measured via spectrophotometer at $500 \mathrm{~nm}$. The content of tannins was determined based on a standard curve of $(0-100 \mu \mathrm{g})$ of tannic acid and expressed as $\mathrm{mg} \mathrm{g}^{-1} \mathrm{DW}$.

For the determination of saponins, $20 \mathrm{~g}$ of dried plant tissue was mixed with $100 \mathrm{~mL}$ of $80 \%(\mathrm{v} / \mathrm{v})$ aqueous ethanol and heated over water bath at $55^{\circ} \mathrm{C}$ for $4 \mathrm{~h}$. The mixture was filtered, and the filtrate was collected, while the residue re-extracted with an additional $100 \mathrm{~mL}$ of $20 \%$ ethanol. The filtrates 
were combined and concentrated to reach $40 \mathrm{~mL}$ over a water bath. About $20 \mathrm{~mL}$ of diethyl ether was added to the concentrate in a separating funnel and shaken vigorously. The aqueous layer was heated over water bath till complete dryness and the dried residue was weighed as total saponins and expressed as $\mathrm{mg} \mathrm{g}^{-1}$ DW [57].

Total flavonoid content was estimated by the $\mathrm{AlCl}_{3}$ colorimetric method [58]. In brief, an extract of $1 \mathrm{mg} \mathrm{L}^{-1}$ was prepared using methanol. Then, one $\mathrm{mL}(5 \%)$ of the previously prepared extract was mixed with $4 \mathrm{~mL}$ distilled water, $0.3 \mathrm{~mL}$ of $\mathrm{NaNO}_{2}(5 \%)$, and $0.3 \mathrm{~mL}$ of $\mathrm{AlCl}_{3}$. The mixture was left to stand for $6 \mathrm{~min}$, then $2 \mathrm{~mL}$ of $\mathrm{NaOH}(1 \mathrm{M})$ was added, and the volume was rained to $10 \mathrm{~mL}$ by distilled water. The absorbance was measured after $15 \mathrm{~min}$ at $510 \mathrm{~nm}$ by a spectrophotometer (Spectronic 21D model, Milton Roy, CA, USA). A standard curve of rutin was prepared, and the amount of the total flavonoids was expressed as $\mathrm{mg}$ rutin equivalent $\mathrm{g}^{-1} \mathrm{DW}$.

The alkaloids were extracted with $10 \%$ acetic acid in ethanol and determined based on the method of Harborne [59]. About $40 \mathrm{~mL}$ of $10 \%$ acetic acid in ethanol was added to $1 \mathrm{~g}$ of dried plant tissue in a beaker and allowed to stand for $4 \mathrm{~h}$. The homogenate was filtered, and the filtrate was concentrated into one-quarter of the original volume over a water bath. The alkaloids were precipitated using concentrated ammonia solution. The residue was dried till constant weight, and the alkaloids were expressed as $\mathrm{mg} \mathrm{g}^{-1} \mathrm{DW}$.

\subsection{Determination of Antioxidant Activity}

The antioxidant potential of the plant samples was evaluated based on the depletion of the color of the stable free radical DPPH, as described by [59]. In summary, equal volumes ( $2 \mathrm{~mL})$ of both $0.15 \mathrm{mM}$ DPPH and plant extracts in different concentrations $\left(1.0,0.8,0.6,0.4,0.2\right.$, and $0.1 \mathrm{mg} \mathrm{mL}^{-1}$, in methanol) were mixed well in the test tubes. The reaction mixture was incubated in a dark condition at room temperature $\left(25^{\circ} \mathrm{C}\right)$ for $30 \mathrm{~min}$. Immediately, the absorbance was measured by a spectrophotometer at $517 \mathrm{~nm}$. A control treatment was achieved using methanol instead of plant extract. Antioxidant activity was expressed as

$$
\text { Scavenging activity }(\%)=\left[1-\left(\mathrm{A}_{\text {sample }} / \mathrm{A}_{\text {control }}\right)\right] \times 100
$$

The $\mathrm{EC}_{50}$ (concentration of plant material that reduces the activity by $50 \%$ ) was calculated graphically.

\subsection{Statistical Analysis}

The data in triplicates of proximate composition, minerals, secondary metabolites were subjected to a one-way ANOVA test after Duncan's test to assess the variance between the five studied geophytes. The analysis was carried out using CoStat (version 6.311, CoHort Software, USA, www.cohort.com).

\section{Conclusions}

The present study revealed that geophytes C. capitatus, C. conglomeratus, E. farctus, L. scindicus, and $C$. capitatus have a considerable amount of the proximate composition as well as macro- and micro-minerals that enabling these plants to be potentially good candidates as forage plants, at least under the arid environments such as the Egyptian deserts. Based on the nutritive values, the geophytes in the present investigation can be ranked as follows: Elymus farctus $>$ C. conglomeratus $>$ Lasiurus scindicus $>$ Panicum turgidum $>$ Cyperus capitatus. However, C. conglomeratus attained high content of various secondary metabolites (total phenolics, tannins, total flavonoids, alkaloids, and saponins). On the other hand, the Cyperaceae members (C. conglomeratus and C. capitatus) showed significant antioxidant activity compared to the grasses. Therefore, we recommend further study to evaluate the anti-nutritional factors of the studied geophytes as well as to experiment on ruminant animals to evaluate their palatability and productivity. 
Author Contributions: Conceptualization, A.M.A.-E. and Y.A.E.-A.; Data curation, A.M.A.-E.; Formal analysis, A.M.A.-E. and Y.A.E.-A.; Investigation, S.L.A.-R., A.M.A.-E., W.A.A.-T., and Y.A.E.-A.; Methodology, A.M.A.-E., and Y.A.E.-A.; Resources, A.M.A.-E.; Validation, S.L.A.-R. and A.M.A.-E.; Writing-original draft, S.L.A.-R., A.M.A.-E., and Y.A.E.-A.; Writing-review \& editing, S.L.A.-R., A.M.A.-E., S.M.A., W.A.A.-T., and Y.A.E.-A.

Funding: This research was supported by Deanship of Scientific Research at King Saud University through research group No (RG-1440-113) and the APC was funded also by Deanship of Scientific Research at King Saud University.

Acknowledgments: The authors express their appreciation to the Deanship of Scientific Research at King Saud University for supporting this work through research group No (RG-1440-113). Also, authors like to sincere Abdulaziz Assaeed, Range Ecology at Plant Production Department, College of Food \& Agriculture Sciences, King Saud University as well as the Department of Botany, Faculty of Science, Mansoura University, Egypt.

Conflicts of Interest: The authors declare that there is no conflict of interest.

\section{References}

1. Zahran, M.A.; El-Amier, Y.A. Non-traditional fodders from the halophytic vegetation of the Deltaic Mediterranean Coastal Desert, Egypt. J. Biol. Sci. 2013, 13, 226-233.

2. Rundel, P.W. Mediterranean-climate ecosystems: Defining their extent and community dominance. In Ecology, Conservation and Management of Mediterranean Climate Ecosystems; Arianoutsou, M., Panastasis, V.P., Eds.; Millpress: Rotterdam, The Netherlands, 2004; pp. 1-12.

3. Berg, L. Introductory Botany: Plants, People, and the Environment; Thomson Higher Education: Belmont, CA, USA, 2007; p. 146.

4. El-Amier, Y.A. Vegetation structure and soil characteristics of five common geophytes in desert of Egypt. Egypt. J. Basic Appl. Sci. 2016, 3, 172-186. [CrossRef]

5. Boval, M.; Dixon, R.M. The importance of grasslands for animal production and other functions: A review on management and methodological progress in the tropics. Animal 2012, 6, 748-762. [CrossRef] [PubMed]

6. O'Mara, F.P. The role of grasslands in food security and climate change. Ann. Bot. 2012, 110, 1263-1270. [CrossRef] [PubMed]

7. Catling, P.M.; McElroy, A.R.; Spicer, K.W. Potential forage value of some eastern Canadian sedges (Cyperaceae: Carex). J. Range Manag. 1994, 47, 226-230. [CrossRef]

8. Zahran, M.A.; El-Amier, Y.A. Ecology and establishment of fiber producing taxa naturally growing in the Egyptian deserts. Egypt. J. Basic Appl. Sci. 2014, 1, 144-150. [CrossRef]

9. Zaki, A.A.; Ross, S.A.; El-Amier, Y.A.; Khan, I.A. New flavans and stilbenes from Cyperus conglomeratus. Phytochem. Lett. 2018, 26, 159-163. [CrossRef]

10. Mashaly, I.A.; El-Halawany, E.F.; Abd El-Gawad, A.M. Fodder potentiality and ecology of some non-conventional forage weeds in the Nile Delta region, Egypt. Egypt. J. Bot. 2007, 47, 119-142.

11. Heneidy, S.Z.; Halmy, M.W. The nutritive value and role of Panicum turgidum Forssk. in the arid ecosystems of the Egyptian desert. Acta Bot. Croat. 2009, 68, 127-146.

12. Sekeroglu, N.; Ozkutlu, F.; Deveci, M.; Dede, O.; Yilmaz, N. Evaluation of some wild plants aspect of their nutritional values used as vegetable in eastern Black Sea region of Turkey. Asian J. Plant Sci. 2006, 5, 185-189.

13. Emelugo, B.N.; Umerie, S.C.; Okonkwo, I.F.; Achufusi, J.N. Evaluation of the tubers and oil of Cyperus rotundus Linn (Cyperaceae). Pak. J. Nutr. 2011, 10, 147-150. [CrossRef]

14. Abdou Bouba, A.; Njintang Yanou, N.; Foyet, H.; Scher, J.; Montet, D.; Mbofung, C.M. Proximate composition, mineral and vitamin content of some wild plants used as spices in Cameroon. Food Nutr. Sci. 2012, 3, 423-432.

15. El-Amier, Y.A.; Abdullah, T.J. Evaluation of nutritional value for four kinds of wild plants in Northern sector of Nile Delta, Egypt. Open J. Appl. Sci. 2015, 5, 393. [CrossRef]

16. Imam, T.S.; Aliyu, F.G.; Umar, H.F. Preliminary phytochemical screening, elemental and proximate composition of two varieties of Cyperus esculentus (tiger nut). Niger. J. Basic Appl. Sci. 2013, 21, 247-251. [CrossRef]

17. Turan, M.; Kordali, S.; Zengin, H.; Dursun, A.; Sezen, Y. Macro and micro mineral content of some wild edible leaves consumed in Eastern Anatolia. Acta Agric. Scand. Sec. B Soil Plant Sci. 2003, 53, 129-137. [CrossRef]

18. Yildirim, E.; Dursun, A.; Turan, M. Determination of the nutrition contents of the wild plants used as vegetables in Upper Coruh Valey. Turk. J. Biol. 2001, 25, 367-371. 
19. Khan, A.D.; Ejaz, N.; Gilani, A.H. The use of berseem clover (Trifoliuma lexandrinum L.) pulp residue, after juice extraction in lamb finishing diets. Archivos de Zootecnia 2002, 51, 291-301.

20. Musco, N.; Koura, I.B.; Tudisco, R.; Awadjihè, G.; Adjolohoun, S.; Cutrignelli, M.I.; Mollica, M.P.; Houinato, M.; Infascelli, F.; Calabrò, S. Nutritional characteristics of forage grown in south of Benin. Asian Australas. J. Anim. Sci. 2016, 29, 51-61. [CrossRef]

21. Pamo, E.T.; Boukila, B.; Fonteh, F.A.; Tendonkeng, F.; Kana, J.R.; Nanda, A.S. Nutritive value of some grasses and leguminous tree leaves of the Central region of Africa. Anim. Feed Sci. Technol. 2007, 135, 273-282. [CrossRef]

22. Borgnia, M.; Vilá, B.L.; Cassini, M.H. Foraging ecology of Vicuña, Vicugna vicugna, in dry Puna of Argentina. Small Rumin. Res. 2010, 88, 44-53. [CrossRef]

23. El-Amier, Y.A.; Ejgholi, A.A. Fodder Potentialities of Three halophytes naturally growing in Egypt. J. Environ. Sci. 2014, 43, 647-662.

24. Capstaff, N.M.; Miller, A.J. Improving the yield and nutritional quality of forage crops. Front. Plant Sci. 2018, 9, 535. [CrossRef] [PubMed]

25. Abdel-Razik, A.F.; Nassar, M.I.; El-Khrisy, E.-D.A.; Dawidar, A.-A.M.; Mabry, T.J. New prenylflavans from Cyperus conglomeratus. Fitoterapia 2005, 76, 762-764. [CrossRef] [PubMed]

26. Gill, K.; Omokanye, A.; Pettyjohn, J.; Elsen, M. Evaluation of forage type barley varieties for forage yield and nutritive value in the Peace region of Alberta. J. Agric. Sci. 2013, 5, 24-36. [CrossRef]

27. Abbasi, M.K.; Tahir, M.M.; Shah, A.H.; Batool, F. Mineral nutrient composition of different ecotypes of white clover and their nutrient credit to soil at Rawalkot Azad Jammu and Kashmir. Pak. J. Bot. 2009, 41, 41-51.

28. Vejnovic, J.; Djuric, B.; Lombnæs, P.; Singh, B.R. Concentration of trace and major elements in natural grasslands of Bosnia and Herzegovina in relation to soil properties and plant species. Acta Agric. Scand. Sec. B Soil Plant Sci. 2018, 68, 243-254. [CrossRef]

29. ARC. Agricultural Research Council: The Nutrient Requirements of Ruminant Livestock; The Gresham Press: London, UK, 1980; p. 351.

30. NRC. Nutrient Requirements of Small Ruminants, National Research Council (US), 1st ed.; National Academy Press: Washington, DC, USA, 2006; p. 362.

31. Parida, A.K.; Das, A.B. Salt tolerance and salinity effects on plants: A review. Ecotoxicol. Environ. Saf. 2005, 60, 324-349. [CrossRef]

32. Canty, M.J.; Fogarty, U.; Sheridan, M.K.; Ensley, S.M.; Schrunk, D.E.; More, S.J. Ergot alkaloid intoxication in perennial ryegrass (Lolium perenne): An emerging animal health concern in Ireland? Ir. Vet. J. 2014, 67, 1-7. [CrossRef]

33. Kara, E.; Sürmen, M. The effects of secondary metabolites of rangeland and pasture plants on the animal health in Mediterranean ecological conditions. J. US China Med. Sci. 2019, 16, 63-72.

34. Al-Hazmi, G.H.; Awaad, A.S.; Alothman, M.R.; Alqasoumi, S.I. Anticandidal activity of the extract and compounds isolated from Cyperus conglomertus Rottb. Saudi Pharm. J. 2018, 26, 891-895. [CrossRef]

35. El Gendy, A.E.-N.G.; Abd El-Gawad, A.M.; Taher, R.F.; El-Khrisy, E.E.-D.A.; Omer, E.A.; Elshamy, A.I. Essential oils constituents of aerial parts of Cyperus capitatus L. and Cyperus difformis L. grown wild in Egypt. J. Essent. Oil Bear. Plants 2017, 20, 1659-1665. [CrossRef]

36. Seabra, R.M.; Moreira, M.M.; Costa, M.C.; Paul, M.I. 6, 3' , 4' -trihydroxy-4-methoxy-5-methylaurone from Cyperus capitatus. Phytochemistry 1995, 40, 1579-1580. [CrossRef]

37. Poutaraud, A.; Michelot-Antalik, A.; Plantureux, S.J.J.o.a. Grasslands: A source of secondary metabolites for livestock health. J. Agric. Food Chem. 2017, 65, 6535-6553. [CrossRef] [PubMed]

38. Glencross, B. Understanding the nutritional and biological constraints of ingredients to optimize their application in aquaculture feeds. In Aquafeed Formulation; Nates, S.F., Ed.; Elsevier: Oxford, MS, USA, 2016; pp. 33-73.

39. Matsuura, H.N.; Fett-Neto, A.G. Plant alkaloids: Main features, toxicity, and mechanisms of action. In Plant Toxins; Gopalakrishnakone, P., Carlini, C., Ligabue-Braun, R., Eds.; Springer: Dordrecht, The Netherlands, 2017; pp. 243-261.

40. Morimoto, M.; Fujii, Y.; Komai, K. Antifeedants in Cyperaceae: Coumaran and quinones from Cyperus spp. Phytochemistry 1999, 51, 605-608. [CrossRef]

41. Abdel-Mogib, M.; Basaif, S.A.; Ezmirly, S.T. Two novel flavans from Cyperus conglomeratus. Pharmazie 2000, 55, 693-695. 
42. Feizbakhsh, A.; Naeemy, A. Chemical composition of the essential oil of Cyperus conglomeratus Rottb. From Iran. Eur. J. Chem. 2011, 8, S293-S296.

43. Hisham, A.; Rameshkumar, K.B.; Sherwani, N.; Al-Saidi, S.; Al-Kindy, S. The composition and antimicrobial activities of Cyperus conglomeratus, Desmos chinensis var. lawii and Cyathocalyx zeylanicus essential oils. Nat. Prod. Commun. 2012, 7, 663-666.

44. El-Desoukey, R.M.A. Phytochemical and antimicrobial activity of Panicum turgidum (thummam) as a grazing herb against some animal pathogens. EC Microbiol. 2017, 5, 22-29.

45. Farag, M.A.; El Fishawy, A.M.; El-Toumy, S.A.; Amer, K.F.; Mansour, A.M.; Taha, H.E. Antihepatotoxic effect and metabolite profiling of Panicum turgidum extract via -qTOF-MS. Pharmacogn. Mag. 2016, 12, S446-S453. [CrossRef]

46. Lee, S.T.; Mitchell, R.B.; Wang, Z.; Heiss, C.; Gardner, D.R.; Azadi, P. Isolation, Characterization, and quantification of steroidal saponins in switchgrass (Panicum virgatum L.). J. Agric. Food Chem. 2009, 57, 2599-2604. [CrossRef]

47. Zaki, A.A.; Ali, Z.; Wang, Y.H.; El-Amier, Y.A.; Khan, S.I.; Khan, I.A. Cytotoxic steroidal saponins from Panicum turgidum Forssk. Steroids 2017, 125, 14-19. [CrossRef] [PubMed]

48. Zakia, A.A.; Qiub, L.; Alib, Z.; Khanb, S.I.; Khanb, I.A. Anti-inflammatory steroidal saponins from Panicum turgidum. J. Agric. Basic Sci. 2016, 1, 1-6.

49. AOAC. Official Methods of Analysis of the Association of Official Analytical Chemists, 15th ed.; Association of Official Analytical Chemists: Arlington, VA, USA, 1990.

50. Pirie, N.W. Protein. In Modern Methods of Plant Analysis IV; Peack, K., Tracey, M.V., Eds.; Springer: Berlin, Germany, 1955; Volume 23.

51. Feteris, A.W. A serum glucose method without protein precipitation. Am. J. Med. Technol. 1965, 31, 17-21. [PubMed]

52. Handel, E.V. Direct micro determinations of sucrose. Anal. Biochem. 1968, 22, 280-283. [CrossRef]

53. Joint FAO. Energy and Protein Requirements Report of a Joint Expert Consultation; Technical Report Series; No 724; World Health Organization: Geneva, Switzerland, 1985.

54. Abu-El-Naga, M.A.; EL-Shazly, K. The Prediction of the Nutritive Value of Animal Feeds from Chemical Analyses. J. Agric. Sci. 1971, 77, 25-31. [CrossRef]

55. Allen, S.E.; Grimshaw, H.M.; Parkinson, J.A.; Quarmby, C.; Roberts, J.D. Chemical Analysis of Ecological Materials; Blackwell Scientific Publications: Oxford, UK; London, UK, 1974.

56. Sadasivam, S.; Manickam, A. Biochemical Methods, 3rd ed.; New Age International Publishers: New Delhi, India, 2008.

57. Obadoni, B.O.; Ochuko, P.O. Phytochemical studies and comparative efficacy of the crude extracts of some haemostatic plants in Edo and Delta States of Nigeria. Glob. J. Pure Appl. Sci. 2002, 8, 203-208. [CrossRef]

58. Chang, C.-C.; Yang, M.-H.; Wen, H.-M.; Chern, J.-C. Estimation of total flavonoid content in propolis by two complementary colorimetric methods. J. Food Drug Anal. 2002, 10, 178-182.

59. Harborne, J. Phytochemical Methods; Chapman and Hall. Ltd.: London, UK, 1973; Volume 4, pp. 49-188.

(C) 2019 by the authors. Licensee MDPI, Basel, Switzerland. This article is an open access article distributed under the terms and conditions of the Creative Commons Attribution (CC BY) license (http://creativecommons.org/licenses/by/4.0/). 